\title{
Forecasting success in equity crowdfunding
}

\author{
Aleksandrina Ralcheva • Peter Roosenboom
}

Accepted: 5 February 2019/Published online: 26 February 2019

(C) The Author(s) 2019

\begin{abstract}
This paper analyzes a large dataset of 2171 equity crowdfunding campaigns launched between the years 2012 and 2017 on two of the world's largest platforms Crowdcube and Seedrs. Our data shows that the equity crowdfunding market has matured: more recent campaigns tend to be launched by larger and older companies with better access to external financing. Given the market's dynamics, we use a rolling three-year window to forecast funding success and develop a simple model based on information that is available at the time of the campaign (e.g., retained equity, external fundraising before the campaign, accelerator attendance, and information about the directors' team). Our proposed forecasting method can be beneficial to both platforms and entrepreneurs for improving outcomes on the equity crowdfunding market.
\end{abstract}

Keywords Equity crowdfunding · Success · Forecasting · Entrepreneurial finance

JEL classification G24 · G32 · L26

A. Ralcheva $(\bowtie) \cdot$ P. Roosenboom

Finance Department, Room T8-29, Rotterdam School of

Management, Erasmus University, Burgemeester Oudlaan 50,

3062 PARotterdam, The Netherlands

e-mail: ralcheva@rsm.nl

\section{Introduction}

In recent years, equity crowdfunding has established itself as a financing alternative to traditional equity funding sources (e.g., business angels and venture capital) and as a popular financing choice among innovative start-up businesses. It offers a marketplace for entrepreneurs to tap into their extended network of family, friends, existing shareholders and customers for raising external funds, while also providing a way to raise additional financing from a large pool of individual investors in exchange for an equity stake in the company. This way, nearly anyone can participate in financing new innovation and reap the benefits of any future value increases, an opportunity that was previously reserved for high-net-worth individuals. With that promise in mind, the ultimate goal of equity crowdfunding has been to bring many more business ideas to fruition, while also contributing to closing the equity funding gap. ${ }^{1}$

Nevertheless, many entrepreneurs are not successful in raising their target amount of money on equity crowdfunding platforms. What is perhaps more important for entrepreneurs than not meeting their financial needs, however, are the significant costs associated with failing a crowdfunding campaign. Unlike with business angels and venture capitalists, who keep the outcomes of their due-diligence process private, online equity crowdfunding participants experience a public failure. For most entrepreneurs participating on the equity

\footnotetext{
${ }^{1}$ For a recent discussion on the equity funding gap, see, e.g., Wilson
} et al. 2018. 
crowdfunding market, the crowdfunding pitch is the first time their business ideas receive public attention, and therefore, generates their initial reputation. Given that first appearances matter (e.g., Coakley et al. 2018 show that the capital raised in an initial equity crowdfunding campaign acts as a reference point for follow-on campaigns), failing a campaign may have an important impact on consecutive funding attempts, ${ }^{2}$ as the reputation of the company and the entrepreneurs themselves is publicly damaged. There is, therefore, great value for entrepreneurs in getting equity crowdfunding right the first time. ${ }^{3}$ As a consequence, the main challenge for platform organizers has been to facilitate this process and improve success rates on their websites, as the reputation of the platform itself is greatly dependent on the reputation of its participants. In this study, we develop a simple forecasting model for equity crowdfunding success that, as we later on show, can be used to predict and improve fundraising outcomes on equity crowdfunding platforms.

Since its inception, researchers in entrepreneurial finance have been greatly concerned with explaining success in equity crowdfunding (see, among others, Ahlers et al. 2015; Vismara 2016, 2018; Vulkan et al. 2016). So far, previous literature has explored different success factors (for a review of these studies, see Mochkabadi and Volkmann 2018), among which are the terms of the equity offering (Ahlers et al. 2015; Vismara 2016), human capital attributes (Piva and Rossi-Lamastra 2018), as well as third party signals (Bapna 2017). The funding dynamics of the campaign (Hornuf and Schwienbacher 2018; Vismara 2018) and the engagement with the crowd by, e.g., providing regular updates (Block et al. 2018), also play an important role for equity crowdfunding outcomes. Considering the rapid growth and development of the equity crowdfunding market, however, very little is known about whether and how these success determinants have evolved, as existing literature has failed to account for differences over time.

\footnotetext{
${ }^{2}$ Our data suggests that it takes a year on average for first-time failed equity crowdfunding campaigns to relaunch. Among those (37 observations in our sample, which initially fail, but launch a second equity crowdfunding campaign), less than half end up being successful (unreported results).

${ }^{3}$ See Signori and Vismara (2018) for the first overview of what happens after a successful equity crowdfunding campaign and Hornuf et al. (2018) for the effect of equity crowdfunding on obtaining followup funding through business angels or venture capitalists.
}

Given that equity crowdfunding is no longer a new unexplored phenomenon and has been around for several years, this paper extends our current knowledge of this marketplace by taking time trends into account. Our goal is to first identify the factors that are associated with success in equity crowdfunding based on a survey of the literature. We then look at how these factors have evolved over time. To reach our conclusions, we rely on data from 2171 pitches launched between 2012 and 2017 on two of the world's largest equity crowdfunding platforms Crowdcube and Seedrs (both based in the United Kingdom). To our knowledge, this is thus far the largest and most comprehensive dataset on equity crowdfunding campaigns. We document that campaigns launched more recently are much more successful at attracting funds from investors. We also provide evidence linking to the equity crowdfunding market having reached some level of maturity as older and more established ventures have started pitching their projects on equity crowdfunding platforms. Furthermore, we add to existing research by expanding the set of potential determinants of success and providing a link between theory and practice. Specifically, we find that besides success factors that are already established in the literature (e.g., retained equity; see Vismara 2016), external fundraising, accelerator attendance, and information about the directors' team also play an important role for explaining success in equity crowdfunding. Although the type of company raising funds via equity crowdfunding platforms has changed over time, we show that these success determinants have retained their importance.

We then use these factors to develop a parsimonious 3-year-rollimg forecasting model to predict the probability of success of equity crowdfunding campaigns. We define success as a binary outcome, which takes the value of one if the campaign target amount has been reached. The choice of this measure is driven by the "allor-nothing" 4 character of both platforms in our sample: entrepreneurs only receive funds if the target amount they have set at the beginning of the campaign has been fully reached. Our model uses a logistic regression approach to forecast equity crowdfunding success utilizing only publicly available information (e.g., percentage equity offered, previous fundraisings, company age,

\footnotetext{
${ }^{4}$ See Cumming, Leboeuf and Schwienbacher (2019) for a discussion on the differences between "keep-it-all" versus "all-or-nothing" crowdfunding models.
} 
the number of company directors). We document our model's predictive ability based on out-of-sample prediction tests, for which we employ the receiver operating characteristic (ROC) curve methodology. This forecasting approach adds a significant contribution to the literature, as it provides a more dynamic and more practically relevant overview of the new phenomenon of equity crowdfunding. While explaining success in equity crowdfunding is important, looking into the determinants of success over a period of time only offers a static snapshot of the equity crowdfunding market. On the contrary, forecasting success by using rolling windows accounts for changes over time and provides an updated and more accurate view of the market's dynamics. Our findings suggest that the success of an equity crowdfunding campaign can be estimated by using a simple model based on information available at the time of the campaign.

In light of the continuous development of the market, this outcome is important and informative for mainly two parties involved in the equity crowdfunding process, entrepreneurs, and platform organizers. Entrepreneurs can take advantage of our proposed prediction model to ex-ante determine their probability of success (or assess their "crowdfunding-readiness") and adjust their campaigns in order to increase their chances of equity crowdfunding success. In some cases, they may decide to postpone launching their campaign, or even not launch it at all and seek alternative more appropriate funding sources. Platform organizers can also benefit from hosting more successful campaigns on their website by incorporating our model in their screening process.

The reminded of the paper is organized as follows. In the next section, we review the existing literature to identify potential determinants of success in equity crowdfunding. Section 3 discusses our empirical setting, followed by the description of our data in Section 4. In Section 5, we report the results of our pooled regression model. Section 6 presents our forecasting model and assesses its out-of-sample performance. We discuss our conclusions and the implications of our findings in Section 7.

\section{The determinants of equity crowdfunding success}

Previous literature has relied heavily on the theory of signaling (Spence 1973) to identify which equity crowdfunding pitch attributes are most likely to influence the investors' decision to pledge funds in a given campaign. Signaling (by effectively transmitting observable indicators of otherwise not directly observable qualities) is an important mechanism to deal with the large information asymmetries inherent to entrepreneurial finance. Using credible signals, entrepreneurs can convey positive information about their company and enable investors to better judge the quality of the available investment opportunities. This is expected to facilitate equity crowdfunding success. In this section, we discuss a number of candidate factors for explaining equity crowdfunding success based on the signaling theory and existing empirical evidence. Among the determinants we consider are different campaign characteristics (target amount, percentage equity), company characteristics (previous backing, accelerator attendance, intellectual property rights protection, and company age) and information about the founders and management team.

\subsection{Target amount and percentage equity}

One of the main challenges an entrepreneur faces when launching an equity crowdfunding campaign is deciding how much money to raise and which percentage equity to sell, thereby setting the company's valuation. This has important implications for the success of the equity crowdfunding campaign, as setting an unrealistically high goal may discourage investors from participating. Indeed, existing empirical evidence from both rewardbased and equity-based crowdfunding suggests that larger targets are negatively associated with success (Mollick 2014; Vulkan et al. 2016). Moreover, the percentage of equity offered (the complement of which is the percentage of equity retained) has important consequences for retaining control after subsequent funding rounds. Offering too much equity to new investors would dilute the current investors' claim on future wealth.

In the framework of signaling theory, retaining equity has traditionally been considered as a strong sign of quality. In their seminal paper, Leland and Pyle (1977) argue that the actions of entrepreneurs "speak" for the quality of their venture and that their willingness to invest in their own project sends a positive signal to investors. For instance, by retaining more equity, entrepreneurs can effectively signal their confidence in the future potential of their business. On the contrary, entrepreneurs who are less dedicated to their company 
are likely to sell a higher amount of equity, that way shifting a higher proportion of potential future losses onto investors. Such behavior is likely to be taken into account by equity crowdfunding investors thereby impacting the success probability of equity crowdfunding campaigns. Previous empirical findings are largely in support of this argument. Both Ahlers et al. (2015) and Vismara (2016) show that the amount of equity offered by the entrepreneurs is negatively associated with equity crowdfunding success.

\subsection{Previous external financing}

In contrast to traditional financing sources for earlystage ventures (business angels and venture capital), equity crowdfunding is specifically aimed at a large group of small "armchair" investors, who typically lack experience in evaluating investment opportunities. Under conditions of high risk and uncertainty where venture quality is not directly observable, individuals are likely to rely on the actions of others when judging about the quality of young companies and making their decision to invest (Stuart et al. 1999). In the context of equity crowdfunding, Vismara (2018) has shown that investors are largely concerned with who has previously invested in the company and that information cascades among individual investors are crucial for the success of equity crowdfunding campaigns. Furthermore, companies previously successful at raising external financing send a strong signal of legitimacy and financial viability, which is likely to increase the investors' confidence in the future performance and value of the company, thus, impacting equity crowdfunding success.

\subsection{Accelerator attendance}

Business accelerators are becoming an increasingly important framework for facilitating young venture success. Accelerator programs are cohort-based and among others offer start-ups seed investment, entrepreneurship schooling, mentoring, and a network. These services can be especially beneficial for young innovative businesses (Hallen et al. 2018) and are associated with an increased new venture performance (Gonzalez-Uribe and Leatherbee 2017), as well as with more seed and venture-capital deals in the region where the accelerator program operates (Fehder and Hochberg 2018). Given the highly selective nature of accelerators and the restricted access to their services, having attended an accelerator may be perceived by investors as a strong signal of venture quality, thus increasing the probability of success of equity crowdfunding campaigns.

\subsection{Intellectual property protection}

By launching a crowdfunding campaign, entrepreneurs publicly disclose their business ideas and strategy, thereby risking misappropriation of that information by others. This introduces the need for protection of the firm's intellectual capital via patents or trademarks. The protection of intellectual property can be viewed as a credible signal that conveys information to investors about the firm's innovation capabilities, the ability to stake technological claims, as well as managerial skills (Long 2002). Extant literature has already recognized the signaling power of patents for raising funds in an IPO and venture capital context (Heeley et al. 2007; Hsu and Ziedonis 2013). However, their signaling value diminishes with firm maturity and the decrease of information asymmetries (Hoenen et al. 2014), which highlights their important effect on start-up financing.

2.5 Company age and information about the founders and management team

There is greater uncertainty associated with younger ventures, as they have limited or no track record of past performance. Younger firms are in general more risky and suffer from greater information asymmetry problems, so one would expect that they are less likely to succeed. To mitigate this concern, investors on equity crowdfunding platforms may turn to information about the founders and the management team (such as the number of directors, their age, and the presence of non-founding directors) as a proxy for the quality of the human capital of the firm. Anecdotal evidence suggests that many investors believe that young people are especially likely to produce more successful new ventures. Human capital attributes have typically been regarded as a critical determinant for the success of entrepreneurial ventures (Florin et al. 2003) and as the most important selection criterion for business angels and venture capital investors (Zacharakis and Meyer 2000). Existing literature has additionally shown that higher human capital is related to superior outcomes in various aspects of the start-up businesses (see, e.g., Colombo and Grilli 2010; Cooper et al. 1994), including the access to additional resources (Baum and Silverman 
2004) and equity crowdfunding success (Piva and Rossi-Lamastra 2018).

\subsection{The role of the platform}

Crowdfunding platforms play an important role on the equity crowdfunding market that goes beyond facilitating the information transfer between entrepreneurs and investors. Over time, platforms have introduced services to help entrepreneurs develop their businesses, successfully launch and effectively manage a crowdfunding pitch, and better engage with their community. In some cases, crowdfunding platforms even take an equity stake in the companies that launch campaigns on their websites. Crowdfunding sites also offer a range of post-campaign services (such as exit assistance and secondary market), which are found to increase the annual number of successful campaigns (Rossi and Vismara 2018). Most importantly, equity crowdfunding platforms undertake due diligence efforts, which mitigate information asymmetries between backers and entrepreneurs. These efforts not only positively impact funding success, but also help to increase the total amount of capital raised (Cumming and Zhang 2018).

At the same time, equity crowdfunding platforms also differ significantly in the range of services they offer and the amount of screening they perform. An important difference from a corporate governance perspective is how voting rights are distributed among investors. Some platforms assign voting rights to individual investors, while others work under a nominee structure. This has direct consequences for success in equity crowdfunding, as platforms delivering individual voting rights are associated with fewer successful offerings (Rossi et al. 2018).

\section{Empirical setting}

The empirical setting of our paper is the equity crowdfunding market in the United Kingdom (the UK). The UK is the world leader in equity crowdfunding with regard to market development, regulatory environment, ${ }^{5}$ and market size. Equity crowdfunding is currently the second most active funding type for high-growth companies in the UK after

\footnotetext{
$\overline{5}$ See Hornuf and Schwienbacher (2017) for a discussion on the impact of the regulatory environment on equity crowdfunding.
}

private equity and venture capital, and equity crowdfunding platforms are leading the way in terms of deal numbers. For example, in 2017, the two top equity crowdfunding platforms, Seedrs and Crowdcube, successfully facilitated more than 140 and more than 130 deals respectively as compared to only 100 deals by angel networks (Beauhurst 2017).

To conduct our study, we rely on data from both Crowdcube and Seedrs. Crowdcube was the first equity crowdfunding platform to open its doors in 2011 in the UK and is authorized and regulated by the Financial Conduct Authority (FCA). Crowdcube is thus far the world's largest equity crowdfunding platform with investments of $£ 625$ million, an investor base of 700 thousand and 821 successful campaigns up until the end of $2018 .^{6}$ Seedrs followed closely and launched in 2012 in the UK and was the first equity crowdfunding platform to receive regulatory approval by the FCA. Seedrs is the most active equity investor in the UK's non-listed high-growth companies with more than $£ 510$ million invested into campaigns and more than 740 deals funded since their launch until the beginning of $2019 .^{7}$ Seedrs also pioneered in setting up the first secondary market for equity crowdfunding shares and by the end of 2018 marked $£ 2$ million traded by almost 3 thousand investors (both buyers and sellers) with shares traded from more than 300 businesses. ${ }^{8}$

To be able to submit a pitch application on Crowdcube, each business must be registered as a UK company, and upload a business plan and financial forecasts. Before the pitch is allowed to go live, each company is subject to due diligence by members of the Crowdcube team and all financials undergo a full review. Similarly, all submitted investment campaigns on Seedrs undergo a comprehensive review process and are only allowed to go live if the due diligence outcome is satisfactory. After being admitted to the platform, business pitches on Crowdcube and Seedrs remain in private mode for a period of time. This is to allow entrepreneurs sufficient room to secure a lead investment and to provide their own network of family, friends, and customers with the opportunity to invest before everyone else. Once the private pitch has reached its potential (as defined by Seedrs) or until $20 \%$ of the overall

\footnotetext{
${ }^{6}$ Source: https://www.crowdcube.com/explore/2018-review (last accessed January 2019)

${ }^{7}$ Source: https://www.seedrs.com/raise (last accessed January 2019)

${ }^{8}$ Source: https://www.seedrs.com/secondary-market (last accessed January 2019)
} 
investment target is reached (in the case of Crowdcube), the campaign becomes publicly accessible.

The campaigns posted on the platforms feature rich content, among which a detailed project description, financial projections, and a video. Entrepreneurs pitch their ideas for a fixed amount of funds and a set amount of shares. Campaigns run for up to 30 days on Crowdcube and up to 60 days on Seedrs. ${ }^{9}$ Both platforms operate in an "all-or-nothing" manner, which means that investors are only committed to providing their pledged funds in case the campaign raises the full amount. If fully funded, firms have the choice to keep their campaign open and allow it to overfund, or close it at the target amount. If unsuccessful, the pitch gets closed and the investors' pledges become void. Unlike Crowdcube (where investors typically become direct shareholders in the businesses they invest in), Seedrs employs a nominee structure, which means that Seedrs acts as a legal shareholder on behalf of the investors, while the investors are the beneficial owners of the shares.

\section{Sample and data description}

\subsection{Sample selection}

We identify campaigns on both Crowdcube and Seedrs via the database of TAB (available on Thomson Reuters Eikon App Studio). ${ }^{10}$ This database contains information about both successful and failed campaigns on Crowdcube and Seedrs during the years 2012 to 2017. In addition, we have scraped data from the websites of Crowdcube and Seedrs during that same period and use these to complement the data we obtained from TAB. This resulted in a list of 2539 successful and failed campaigns. Table 1 provides an overview of our selection criteria.

We exclude 97 campaigns from non-UK firms, 42 campaigns that have issued (convertible) bonds instead of equity and 65 campaigns for other reasons. We lose 164 campaigns because of missing information about the campaign or company. Our final sample therefore consists of 2171 campaigns (by 1932 unique

\footnotetext{
$\overline{9}$ All these terms and conditions have not always been applicable, but only got introduced and updated as platforms developed over time (e.g., in the 2012-2015 period Crowdcube pitches remained live for 60 days and did not require a lead investment of 20\%).

${ }^{10}$ See https://www.insidetab.io/ (last accessed January 2019).
}

companies) launched on either Crowdcube or Seedrs between January 1, 2012 and December 31, 2017. 189 of these companies launched more than one campaign (total of 239 follow-on campaigns). Out of the 2171 campaigns 961 are successful at reaching their targets.

\subsection{Variables, definitions, and data sources}

Table 2 provides an overview of the variables used in the analysis. The main variable of our interest is equity crowdfunding success. We define equity crowdfunding success as a binary outcome, which takes the value of one if the equity crowdfunding campaign achieved at least $100 \%$ of its target (values above $100 \%$ are possible in the case of overfunding), and zero otherwise. The choice of this measure is driven by the "all-or-nothing" character of Seedrs and Crowdcube. The independent variables in our study are based on different campaign, company and director characteristics. We retrieve information about the campaigns (such as the date the campaign has been launched, the target, the amount of equity offered, the amount raised, whether it's a first time campaign, and whether it was launched on Seedrs or Crowdcube). For this purpose we rely on the TAB database, but also on the individual websites of the Crowdcube and Seedrs platforms.

We gather information about the companies' previous financing from the Beauhurst database, which gives us detailed access to the transaction histories of highgrowth companies in the UK. Based on that we define a dummy variable external financing that takes the value of 1 if the company raised money from grants, business angels, angel networks, family offices, corporate investors, venture capital and/or private equity prior to launching a campaign. The Beauhurst platform also contains data on 200 UK accelerators, which offer programs to start-up companies and provide services such as mentoring, business education, accessing networks of contacts, office spaces, etc. Based on that information we define a dummy variable accelerator attendance that equals 1 if the company has been part of an accelerator program prior to launching a campaign. Examples of accelerators that support businesses in our sample include among others: Accelerator Academy, Wayra, Entrepreneurial Spark, Ignite Accelerator, Grow to Go, Octopus Labs Accelerator, Seedcamp and the UK Accelerator Programme.

Information on other company and director characteristics we retrieve from different sections of the Orbis 
Table 1 Sample selection criteria

\begin{tabular}{|c|c|c|c|c|}
\hline & Crowdcube & Seedrs & Total & Percentage \\
\hline Number of campaigns (2012-2017) & 1370 & 1169 & 2539 & $100.00 \%$ \\
\hline \multicolumn{5}{|l|}{ Reason for exclusion } \\
\hline Campaigns by non-UK firms & 14 & 83 & 97 & $3.82 \%$ \\
\hline (Convertible) bonds & 24 & 18 & 42 & $1.65 \%$ \\
\hline Other & 2 & 63 & 65 & $2.56 \%$ \\
\hline Missing information & 27 & 137 & 164 & $6.46 \%$ \\
\hline Campaigns in sample & 1303 & 868 & 2171 & $85.51 \%$ \\
\hline By \# companies & 1187 & 745 & 1932 & \\
\hline \multicolumn{5}{|l|}{ Out of which } \\
\hline Follow-on campaigns & 116 & 123 & 239 & \\
\hline By \# companies & 98 & 91 & 189 & \\
\hline
\end{tabular}

Other reasons for exclusion include raising money to pay for an acquisition (1 Seedrs campaign), raising money by investment funds (23 Seedrs campaigns), launching a campaign to offer investors the opportunity to exercise their pre-emption rights (39 Seedrs campaigns), raising money by community interest companies (2 Crowdcube campaigns). Missing information concerns missing information about the campaign and/or company

database. For example, to define our intellectual property rights dummy, we collect data on the number of patents and trademarks from the Intellectual property section of the database. On Orbis we also have access to legal (e.g., incorporation date) and director data (e.g., number of directors), including personal data (such as the birthdates of the directors). We use these to calculate the company age and average director age. Additionally, we define a dummy variable non-founding directors that equal 1 if non-founding directors (directors that were appointed after the incorporation of the firm) are sitting on the board of the company at the time of the crowdfunding campaign.

\subsection{Descriptive statistics}

Tables 3, 4, 5, and 6 present the descriptive statistics of the whole sample, Crowdcube and Seedrs separately, the sample split between successful and unsuccessful campaigns, as well as for different periods in time. Table 3 shows that the average success rate in our sample is $44 \%$.

For explaining equity crowdfunding success we first consider two important campaign characteristics - the target amount and the percentage of equity offered. The average target amount in our sample is around $£ 250,000$ and ranges between as little as $£ 700$ and $£ 5$ million. The average equity offered is around $14 \%$, which suggest that on average $86 \%$ of the equity is retained by the initial owners of the company. Campaigns on Crowdcube tend to be significantly larger than those launched on Seedrs and give up a significantly larger proportion of their equity (Table 4).

We further look how different company characteristics (such as age, intellectual property rights, external financing and accelerator attendance) may affect equity crowdfunding success. About one third of the campaigns in our sample were launched by companies which had previously successfully raised external funds (e.g., by grants or business angels). On average, these companies (conditional on raising external funds) were able to secure over $£ 1$ million of funds in the form of equity investments and over $£ 250,000$ in the form of grants (unreported results). Out of all the campaigns in our sample, 159 were launched by businesses which attended an accelerator program. About $11 \%$ of the companies in our sample hold patents or trademarks, and have thereby protected their intellectual property (more so in the case of Crowdcube). The companies in our sample are on average 2 years and 9 months old, but companies on Seedrs tend to be somewhat younger than those on Crowdcube.

The main responsibility for effectively promoting and successfully managing not only the business but also the equity crowdfunding pitch lies largely in the hands of the entrepreneur and his/her team. We, therefore, consider several characteristics relating to the director team and its composition (i.e., the number of 
Table 2 Variables and variable definitions

\begin{tabular}{|c|c|c|}
\hline & Variable description & Data source \\
\hline Success & $\begin{array}{l}\text { Dummy variable that equals } 1 \text {, if the campaign reached } 100 \% \text { of its } \\
\text { target, and } 0 \text { otherwise. }\end{array}$ & TAB, Crowdcube and Seedrs websites \\
\hline $\begin{array}{l}\text { Target amount } \\
\quad \text { (in } £ \text { ) }\end{array}$ & The target amount of the campaign. & TAB, Crowdcube and Seedrs websites \\
\hline $\begin{array}{l}\text { Equity offered } \\
\qquad \%)\end{array}$ & The percentage of equity offered in the campaign. & TAB, Crowdcube and Seedrs websites \\
\hline $\begin{array}{l}\text { External } \\
\quad \text { financing }\end{array}$ & $\begin{array}{l}\text { Dummy variable that equals } 1 \text {, if the company has raised external } \\
\text { capital prior to launching the campaign, and } 0 \text { otherwise. }\end{array}$ & Beauhurst \\
\hline $\begin{array}{l}\text { Accelerator } \\
\text { attendance }\end{array}$ & $\begin{array}{l}\text { Dummy variable that equals } 1 \text {, if the company has previously attended } \\
\text { an accelerator program, and } 0 \text { otherwise. }\end{array}$ & Beauhurst \\
\hline $\begin{array}{l}\text { Intellectual } \\
\text { property } \\
\text { rights }\end{array}$ & $\begin{array}{l}\text { Dummy variable that equals } 1 \text {, if the company has protected its } \\
\text { intellectual property via patents and/or trademarks, and } 0 \text { otherwise. }\end{array}$ & $\begin{array}{l}\text { ORBIS/Intellectual property/Patents \& Trade- } \\
\text { marks }\end{array}$ \\
\hline Age (in days) & $\begin{array}{l}\text { The company age in days at the start of the campaign calculated as the } \\
\text { difference between the starting date of the campaign and the } \\
\text { incorporation date of the company. }\end{array}$ & $\begin{array}{l}\text { ORBIS/Legal \& accounting information/Legal in- } \\
\text { formation }\end{array}$ \\
\hline $\begin{array}{r}\text { Number of } \\
\text { directors }\end{array}$ & The number of directors at the start of the campaign. & $\begin{array}{l}\text { ORBIS/Directors, managers, contacts \& } \\
\text { advisors/Directors \& Managers }\end{array}$ \\
\hline Director age & $\begin{array}{l}\text { The average age of the directors (in years) at the start of the campaign } \\
\text { calculated as the average difference between the starting date of the } \\
\text { campaign and the birthdate of each director. }\end{array}$ & $\begin{array}{l}\text { ORBIS/Directors, managers, contacts \& } \\
\text { advisors/Directors \& Managers/Other personal } \\
\text { information }\end{array}$ \\
\hline $\begin{array}{l}\text { Non-founding } \\
\text { directors }\end{array}$ & $\begin{array}{l}\text { Dummy variable that equals } 1 \text {, if the company has appointed one or } \\
\text { more non-founding directors, and } 0 \text { otherwise. }\end{array}$ & $\begin{array}{l}\text { ORBIS/Directors, managers, contacts \& } \\
\text { advisors/Directors \& Managers }\end{array}$ \\
\hline $\begin{array}{l}\text { Follow-on } \\
\text { campaign }\end{array}$ & $\begin{array}{l}\text { Dummy variable that equals } 1 \text {, if the campaign is a follow-on cam- } \\
\text { paign (i.e., the company had previously launched a campaign on the } \\
\text { same platform), and } 0 \text { otherwise. }\end{array}$ & TAB, Crowdcube and Seedrs websites \\
\hline Seedrs & $\begin{array}{l}\text { Dummy variable that equals } 1 \text {, if the campaign was launched on } \\
\text { Seedrs, and } 0 \text { otherwise. }\end{array}$ & TAB, Crowdcube, and Seedrs websites \\
\hline
\end{tabular}

directors, the director age, and the presence of nonfounding directors). The average director in our sample is 40 years of age and most companies employ more than one director. Almost half of the campaigns are launched by companies which have one or more nonfounding directors on board.

As discussed in Section 2.6., the platform itself also plays an important role in the equity crowdfunding market. We include a platform dummy variable (Seedrs) to control for the availability of distinct platform characteristics that may lead to different success outcomes (e.g., Seedrs offers nominee structure). We additionally take into account whether each of the campaigns in our sample represents a first time pitch or a follow-on fundraising. The probability of equity crowdfunding success for follow-on campaigns is likely to be higher, as the business has already undergone the market's scrutiny.

Table 5 presents the difference in means and medians between successful and unsuccessful campaigns. Successful pitches tend to have higher valuations on average as derived by their higher targets and lower proportions of equity on offer. Companies that launched successful pitches were more often able to secure external funds from other sources prior to their equity crowdfunding campaign, were more often part of an accelerator program and more often protected their intellectual property. Successful companies also employed more and younger directors, as well as more nonfounding directors. Most follow-on campaigns ended up being successful.

Table 6 reports the evolution of equity crowdfunding campaign attributes over time (2012-2017). According to Table 5, campaigns launched more recently (20152017) are much more likely to be successful than campaigns launched in the early days (2011-2014) of Crowdcube and Seedrs. The average target amounts and equity offered have also steadily increased over time. More recent campaigns are launched by companies, which were more often successful at raising funds externally, attended accelerator programs or protected 
Table 3 Descriptive statistics

\begin{tabular}{|c|c|c|c|c|c|c|}
\hline & Obs. & Mean & Median & Std. dev. & Min & Max \\
\hline Success & 2171 & 0.443 & 0 & 0.497 & 0 & 1 \\
\hline Target amount (in $£$ ) & 2171 & 249,348 & 150,000 & 346,230 & 688 & $5,000,000$ \\
\hline Equity offered (\%) & 2171 & 13.545 & 11.760 & 8.179 & 0.060 & 70 \\
\hline External financing & 2171 & 0.324 & 0 & 0.468 & 0 & 1 \\
\hline Accelerator attendance & 2171 & 0.073 & 0 & 0.261 & 0 & 1 \\
\hline Intellectual property rights & 2171 & 0.111 & 0 & 0.314 & 0 & 1 \\
\hline Age (in days) & 2171 & 1014 & 713 & 1088 & 1 & 11,166 \\
\hline Number of directors & 2171 & 2.337 & 2 & 1.474 & 1 & 16 \\
\hline Director age (in years) & 2171 & 42.055 & 42 & 10.408 & 20 & 79 \\
\hline Non-founding directors & 2171 & 0.473 & 0 & 0.499 & 0 & 1 \\
\hline Follow-on campaign & 2171 & 0.110 & 0 & 0.313 & 0 & 1 \\
\hline
\end{tabular}

This table presents the descriptive statistics of the variables used in this study. See Table 2 for variable definitions

their intellectual property. In the period of 2015 to 2017 , the companies pitching on both equity crowdfunding platforms were older and employed larger boards of directors, including more non-founding directors. Taken together this evidence suggests that the equity crowdfunding market has matured over time and that more established companies have turned to equity crowdfunding as a viable financing alternative. To control for these changing market conditions and for not readily observable changes in the way platforms operate, we include year fixed effects in our regressions on the determinants of success.

\section{Empirical results for the pooled sample}

To first identify the determinants of equity crowdfunding success, we conduct our analysis on the pooled sample of campaigns launched between 2012 and 2017 on both Crowdcube and Seedrs. Additionally, we look into how these determinants might differ over the different platforms and time periods. Table 7 presents the results of the logistic regressions for the entire sample, for each of the Crowdcube and Seedrs samples pooled over the entire sample period, and for the early (2012-2014) and late (2015-2017) sample periods. All models include year,

Table 4 Differences in means and medians between Crowdcube and Seedrs campaigns

\begin{tabular}{|c|c|c|c|c|c|c|c|}
\hline & \multicolumn{2}{|c|}{ Crowdcube $(\mathrm{N}=1303)$} & \multicolumn{2}{|c|}{ Seedrs $(N=868)$} & \multicolumn{3}{|c|}{ Test for difference in } \\
\hline & Mean & Median & Mean & Median & Means & Medians & \\
\hline Success & 0.431 & 0 & 0.460 & 0 & -1.3 & & \\
\hline Target amount (in $£$ ) & 275,264 & 150,000 & 210,444 & 100,002 & $4.29 * * *$ & 8.56 & $* * *$ \\
\hline Equity offered (\%) & 14.883 & 13.510 & 11.537 & 10 & $9.53 * * *$ & 10.17 & $* * *$ \\
\hline External financing & 0.328 & 0 & 0.318 & 0 & 0.47 & & \\
\hline Accelerator attendance & 0.068 & 0 & 0.082 & 0 & -1.25 & & \\
\hline Intellectual property rights & 0.129 & 0 & 0.084 & 0 & $3.26^{* * *}$ & & \\
\hline Age (in days) & 1,116 & 776 & 860 & 605 & $5.40 * * *$ & 4.57 & $* * *$ \\
\hline Number of directors & 2.396 & 2 & 2.249 & 2 & $2.28 * *$ & & \\
\hline Director age (in years) & 43.208 & 43 & 40.323 & 40 & $6.38 * * *$ & 5.07 & $* * *$ \\
\hline Non-founding directors & 0.493 & 0 & 0.441 & 0 & $2.39 * *$ & & \\
\hline Follow-on campaign & 0.089 & 0 & 0.142 & 0 & $-3.85 * * *$ & & \\
\hline
\end{tabular}

This table presents the mean and median statistics of Crowdcube and Seedrs campaigns separately. The last two columns presents the difference in means and medians between Crowdcube and Seedrs campaigns. ***, ** and $*$ denote statistical significance at the $1 \%, 5 \%$ and $10 \%$ level, respectively. See Table 2 for variable definitions 
Table 5 Difference in means and medians between successful and unsuccessful campaigns

\begin{tabular}{|c|c|c|c|c|c|c|c|}
\hline & \multicolumn{2}{|c|}{ Successful (N=961) } & \multicolumn{2}{|c|}{ Unsuccessful $(\mathrm{N}=1210)$} & \multicolumn{3}{|c|}{ Test for difference in } \\
\hline & Mean & Median & Mean & Median & Means & Medians & \\
\hline 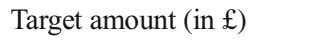 & 311,511 & 150,000 & 199,977 & 149,998 & $7.55 * * *$ & 0.00 & \\
\hline Equity offered (\%) & 11.501 & 10 & 15.168 & 14 & $-8.42 * * *$ & -11.04 & $* * *$ \\
\hline External financing & 0.461 & 0 & 0.215 & 0 & $12.60 * * *$ & & \\
\hline Accelerator attendance & 0.122 & 0 & 0.035 & 0 & $7.84 * * *$ & & \\
\hline Intellectual property rights & 0.140 & 0 & 0.088 & 0 & $3.91 * * *$ & & \\
\hline Age (in days) & 1,029 & 771 & 1,002 & 652 & 0.58 & 3.36 & $* * *$ \\
\hline Number of directors & 2.612 & 2 & 2.119 & 2 & $7.84 * * *$ & & \\
\hline Director age (in years) & 41.408 & 42 & 42.568 & 42 & $-2.58 * * *$ & & \\
\hline Non-founding directors & 0.547 & 1 & 0.413 & 0 & $6.27 * * *$ & & \\
\hline Follow-on campaign & 0.185 & 0 & 0.050 & 0 & $10.20 * * *$ & & \\
\hline Seedrs & 0.415 & 0 & 0.388 & 0 & 1.30 & & \\
\hline
\end{tabular}

This table presents the mean and median statistics of successful and unsuccessful campaigns separately. The last two columns presents the difference in means and medians between successful and unsuccessful campaigns. $* * *, * *$ and $*$ denote statistical significance at the $1 \%, 5 \%$ and $10 \%$ level, respectively. See Table 2 for variable definitions

industry and platform fixed effects when appropriate, as well as heteroscedasticity-consistent standard errors. The correlation matrix (available in the Appendix Table 10) reveals no severe problem of multicollinearity. The fourth and seventh column of Table 7 report the $\chi^{2}$ values from two pooled regression models that include interaction variables for the Seedrs sample as compared to the Crowdcube sample (i.e., the difference between Model
2 and 3) and the early sample period as compared to the late sample period (i.e., the difference between Model 4 and 5), respectively.

Our findings are largely consistent with existing empirical evidence but also offer some additional insights. According to our results for the full sample (Model 1), the target amount and the percentage equity offered are significantly negatively associated with equity crowdfunding

Table 6 Equity crowdfunding over time

\begin{tabular}{|c|c|c|c|c|c|c|c|}
\hline & 2012 & 2013 & 2014 & 2015 & 2016 & 2017 & F-test \\
\hline Success & 0.167 & 0.266 & 0.412 & 0.525 & 0.496 & 0.623 & $38.25 * * *$ \\
\hline Target amount (in $£$ ) & 136,504 & 127,434 & 193,337 & 274,768 & 288,192 & 399,556 & $33.53 * * *$ \\
\hline Equity offered (\%) & 19.562 & 16.848 & 12.485 & 12.192 & 12.283 & 11.381 & $49.33 * * *$ \\
\hline External financing & 0.049 & 0.110 & 0.298 & 0.393 & 0.428 & 0.491 & $49.81 * * *$ \\
\hline Accelerator attendance & 0.005 & 0.020 & 0.069 & 0.073 & 0.109 & 0.122 & $10.23 * * *$ \\
\hline Intellectual property rights & 0.044 & 0.064 & 0.090 & 0.131 & 0.156 & 0.137 & $6.48 * * *$ \\
\hline Age (in days) & 725 & 725 & 981 & 990 & 1,156 & 1,323 & $16.20 * * *$ \\
\hline Number of directors & 1.768 & 1.934 & 2.227 & 2.637 & 2.513 & 2.578 & $19.25 * * *$ \\
\hline Director age (in years) & 40.840 & 42.663 & 42.735 & 42.462 & 41.199 & 41.968 & 1.83 \\
\hline Non-founding directors & 0.246 & 0.324 & 0.464 & 0.560 & 0.537 & 0.565 & $22.22 * * *$ \\
\hline Follow-on campaign & 0.030 & 0.087 & 0.098 & 0.110 & 0.102 & 0.193 & $8.98 * * *$ \\
\hline Seedrs & 0.281 & 0.396 & 0.330 & 0.445 & 0.475 & 0.402 & $6.76 * * *$ \\
\hline Number of successes & 34 & 92 & 156 & 224 & 210 & 245 & \\
\hline Total observations & 203 & 346 & 379 & 427 & 423 & 393 & \\
\hline
\end{tabular}

This table shows the mean statistics for each year from 2012 to 2017 . The last column shows an F-test testing for differences over time. ***, $* *$ and $*$ denote statistical significance at the $1 \%, 5 \%$ and $10 \%$ level, respectively. See Table 2 for variable definitions 
Table 7 The determinants of equity crowdfunding success

\begin{tabular}{|c|c|c|c|c|c|c|c|c|c|c|c|c|}
\hline \multirow[b]{2}{*}{ Intercept } & \multirow{2}{*}{$\begin{array}{l}\text { Model (1): } \\
\text { Full Sample } \\
\begin{array}{r}3.045^{* * *} \\
(2.74)\end{array}\end{array}$} & \multicolumn{2}{|c|}{$\begin{array}{l}\text { Model (2): } \\
\text { Crowdcube }\end{array}$} & \multicolumn{2}{|c|}{$\begin{array}{l}\text { Model (3): } \\
\text { Seedrs }\end{array}$} & \multicolumn{2}{|c|}{$\begin{array}{l}\text { Difference } \\
\text { (2) vs. (3) }\end{array}$} & \multicolumn{2}{|l|}{$\begin{array}{l}\text { Model (4): } \\
\text { 2012-2014 }\end{array}$} & \multicolumn{2}{|l|}{$\begin{array}{l}\text { Model (5): } \\
\text { 2015-2017 }\end{array}$} & $\begin{array}{l}\text { Difference } \\
\text { (4) vs. (5) }\end{array}$ \\
\hline & & $\begin{array}{l}3.581 \\
(2.15)\end{array}$ & $* *$ & $\begin{array}{l}2.248 \\
(1.37)\end{array}$ & & & & $\begin{array}{l}2.827 \\
(1.51)\end{array}$ & & $\begin{array}{l}3.348 \\
(2.41)\end{array}$ & $* *$ & \\
\hline Target amount (ln) & $\begin{array}{c}-0.107 * \\
(-1.69)\end{array}$ & $\begin{array}{l}-0.077 \\
(-0.82)\end{array}$ & & $\begin{array}{l}-0.091 \\
(-0.97)\end{array}$ & & 0.01 & & $\begin{array}{l}-0.130 \\
(-1.14)\end{array}$ & & $\begin{array}{l}-0.023 \\
(-0.32)\end{array}$ & & 0.63 \\
\hline Equity offered & $\begin{array}{r}-0.032 * * * \\
(-4.33)\end{array}$ & $\begin{array}{l}-0.030 \\
(-3.33)\end{array}$ & $* * *$ & $\begin{array}{l}-0.043 \\
(-2.98)\end{array}$ & $* * *$ & 0.59 & & $\begin{array}{l}-0.026 \\
(-2.44)\end{array}$ & $* *$ & $\begin{array}{l}-0.044 \\
(-4.34)\end{array}$ & $* * *$ & 1.39 \\
\hline External financing & $\begin{array}{r}0.689 * * * \\
(5.68)\end{array}$ & $\begin{array}{l}0.720 \\
(4.58)\end{array}$ & $* * *$ & $\begin{array}{l}0.542 \\
(2.69)\end{array}$ & $* * *$ & 0.49 & & $\begin{array}{l}1.003 \\
(4.43)\end{array}$ & $* * *$ & $\begin{array}{l}0.565 \\
(3.95)\end{array}$ & $* * *$ & 2.67 \\
\hline Accelerator attendance & $\begin{array}{r}0.830 * * * \\
(3.95)\end{array}$ & $\begin{array}{l}0.563 \\
(2.13)\end{array}$ & $* *$ & $\begin{array}{l}1.230 \\
(3.31)\end{array}$ & $* * *$ & 2.14 & & $\begin{array}{l}1.620 \\
(3.65)\end{array}$ & $* * *$ & $\begin{array}{l}0.638 \\
(2.78)\end{array}$ & $* * *$ & $3.86 * *$ \\
\hline Intellectual property rights & $\begin{array}{l}0.037 \\
(0.22)\end{array}$ & $\begin{array}{l}0.136 \\
(0.64)\end{array}$ & & $\begin{array}{l}0.005 \\
(0.02)\end{array}$ & & 0.13 & & $\begin{array}{l}0.120 \\
(0.37)\end{array}$ & & $\begin{array}{l}-0.091 \\
(-0.47)\end{array}$ & & 0.31 \\
\hline Age $(\ln )$ & $\begin{array}{r}-0.079 * * \\
(-1.96)\end{array}$ & $\begin{array}{l}-0.195 \\
(-3.13)\end{array}$ & $* * *$ & $\begin{array}{l}-0.023 \\
(-0.42)\end{array}$ & & 4.22 & $* *$ & $\begin{array}{l}-0.096 \\
(-1.79)\end{array}$ & * & $\begin{array}{l}-0.031 \\
(-0.50)\end{array}$ & & 0.63 \\
\hline Number of directors (ln) & $\begin{array}{r}0.386^{* * * *} \\
(3.33)\end{array}$ & $\begin{array}{l}0.317 \\
(2.10)\end{array}$ & $* *$ & $\begin{array}{l}0.448 \\
(2.34)\end{array}$ & $* *$ & 0.29 & & $\begin{array}{r}0.300 \\
(1.62)\end{array}$ & & $\begin{array}{l}0.434 \\
(2.89)\end{array}$ & $* * *$ & 0.32 \\
\hline Director age $(\ln )$ & $\begin{array}{r}-0.661 * * * \\
(-3.19)\end{array}$ & $\begin{array}{l}-0.574 \\
(-2.13)\end{array}$ & $* *$ & $\begin{array}{l}-0.662 \\
(-1.95)\end{array}$ & $* *$ & 0.04 & & $\begin{array}{l}-0.599 \\
(-1.88)\end{array}$ & $*$ & $\begin{array}{l}-0.642 \\
(-2.29)\end{array}$ & $* *$ & 0.01 \\
\hline Non-founding directors & $\begin{array}{l}-0.019 \\
(-0.14)\end{array}$ & $\begin{array}{l}0.005 \\
(0.03)\end{array}$ & & $\begin{array}{l}-0.009 \\
(-0.04)\end{array}$ & & 0.00 & & $\begin{array}{l}0.302 \\
(1.45)\end{array}$ & & $\begin{array}{l}-0.209 \\
(-1.26)\end{array}$ & & $3.69 *$ \\
\hline Follow-on campaign & $\begin{array}{r}1.133 * * * \\
(6.42)\end{array}$ & $\begin{array}{l}0.734 \\
(3.03)\end{array}$ & $* * *$ & $\begin{array}{l}1.478 \\
(5.39)\end{array}$ & $* * *$ & 4.13 & $* *$ & $\begin{array}{l}1.443 \\
(5.04)\end{array}$ & $* * *$ & $\begin{array}{l}1.054 \\
(4.92)\end{array}$ & $* * *$ & 1.19 \\
\hline Seedrs & $\begin{array}{l}-0.106 \\
(-0.99)\end{array}$ & & & & & & & $\begin{array}{l}0.121 \\
(0.62)\end{array}$ & & $\begin{array}{l}-0.214 \\
(-1.67)\end{array}$ & & 2.05 \\
\hline Overall & & & & & & 13.06 & & & & & & 16.89 \\
\hline Industry fixed effects & Yes & Yes & & Yes & & & & Yes & & Yes & & \\
\hline Year fixed effects & Yes & Yes & & Yes & & & & & & & & \\
\hline Number of successes & 961 & 562 & & 399 & & & & 282 & & 679 & & \\
\hline Total observations & 2,171 & 1,303 & & 868 & & & & 928 & & 1,243 & & \\
\hline Log likelihood & $-1,274$ & -768.78 & & -482.38 & & & & -491.23 & & -782.13 & & \\
\hline Pseudo R sq. & 0.145 & 0.137 & & 0.195 & & & & 0.138 & & 0.087 & & \\
\hline Wald $x$ sq. & $315.62 * * *$ & 194.53 & $* * *$ & 139.82 & $* * *$ & & & 116.44 & $* * *$ & 117.63 & $* * *$ & \\
\hline
\end{tabular}

This table reports the coefficient estimates of logit regressions for the full sample and the four subsamples: Crowdcube, Seedrs, early period, and late period samples. The dependent variable is success, a dummy variable that equals 1 if an equity crowdfunding campaign reached its target and 0 otherwise. All specifications include industry fixed effects based on the main sections of NACE Rev. 2. Z-values are in parentheses. The fourth and the last columns shows the difference between the coefficients of Model (2) and (3) and Model (4) and (5), respectively, tested with a Wald $(\chi$ sq.) test on the interaction term of the respective coefficient in the logistic regression for which the two samples are pooled. In other words, a Seedrs dummy variable is multiplied to each variable in a pooled Crowdcube and Seedrs model for a (2) vs. (3) difference, and a late period (2015-2017) dummy variable is multiplied to each variable in a pooled all year model for a (4) vs. (5) difference. $* * * * *$ and $*$ denote statistical significance at the $1 \%, 5 \%$ and $10 \%$ level, respectively. See Table 2 for variable definitions

success (at the $10 \%$ and $1 \%$ level respectively). This indicates that campaigns that sought lower amounts of capital and entrepreneurs who retained larger proportion of their equity are more likely to be successful in raising their funds on Crowdcube and Seedrs. Similar results were reported for Kickstarter for the effect of the target amount (Mollick 2014) and for the Australian platform ASSOB (Ahlers et al. 2015) and both Crowdcube and 
Seedrs (Vismara 2016) for the effect of the percentage of equity offered. Both our external financing and accelerator attendance variables are positive and significant across all models. Companies that previously raised external financing or attended accelerator programs are more likely to be successful in equity crowdfunding their projects. Intellectual property rights do not seem to play a significant role in determining success.

Contrary to our expectations, age is significantly negatively related to success in our setting. This effect is especially pronounced for the sample of Crowdcube campaigns and not significant for the sample of Seedrs campaigns. However, equity crowdfunding platforms are by design targeted towards young early stage companies. We interpret this result as the "crowd" opting for young innovative companies with unexplored upward potential, which cater better to the preferences of the "unicorn seeking" type investors populating the equity crowdfunding market (Estrin et al. 2018). Similar to the findings of Vismara (2016), we show that the number of directors is positively associated with equity crowdfunding success for the full sample, as well as for each of the Crowdcube and Seedrs samples. Director age, however, negatively impacts the probability of equity crowdfunding success, while the presence of non-founding directors does not seem to play a role for funding success in our setting. These findings reflect how different directors' characteristics are perceived by investors, who seem to put more emphasis on larger but younger director teams.

Based on our data, campaigns launched on Seedrs do not seem to exhibit significant differences in success probabilities as compared to those launched on Crowdcube. At the same time and according to our expectations, follow-on campaigns are much more likely to be successful as compared to first time pitches on both platforms. This effect is especially large (a marginal effect of 0.278 ) and significant at the $1 \%$ level.

As discussed in the previous section, we identified that campaigns launched in the early half of our sample period (2012-2014) differ significantly from the campaigns launched in the late half of the same period (2015-2017) due to the maturing of the market. We want to further investigate whether these developments have also affected the determinants of equity crowdfunding success over time. We address this question in the last column of Table 6, where we show that Model 4 and 5 are not structurally different from each other (insignificant overall $\chi^{2}$ statistic). This suggests that even though the equity crowdfunding market has evolved over time, the relationships underlying the success of equity crowdfunding campaigns have not changed significantly.

Overall, our logistic regression models perform well across all samples and are able to capture a number of important determinants for equity crowdfunding success. We find that the percentage equity offered, external fundraising, accelerator attendance, the number and age of directors, and follow-on raises significantly explain success on both equity crowdfunding platforms Crowdcube and Seedrs.

\section{Out-of-sample prediction model}

In this section, we develop parsimonious forecasting models to predict the probability of success of equity crowdfunding campaigns based on the previously reported models of the determinants of success. We then examine the strictly out-of-sample predictive performance of our success prediction models.

\subsection{Results of the parsimonious forecasting models}

Following the standard approach in the forecasting literature (e.g., Demers and Joos 2007), we use only the subset of explanatory variables with significant explanatory power to develop our models. To identify those we first estimate the full original model from the previous section on just the campaigns included in our estimation window. We then retain only those predictors that are significant from the first stage and rerun the regressions. This way we strike a balance between overfitting the model and its ability to describe the data. To develop annual forecasts of success on equity crowdfunding platforms, we use three-year rolling estimation windows in order to ensure that our estimation process is updated. For example, we use data from 2012 to 2014 to predict the likelihood of success in 2015, we then roll the estimation window forward by one year, i.e., use data from 2013 to 2015 to predict the likelihood of success in $2016 .{ }^{11}$ The parsimonious models for each year are shown in Table 8 .

\footnotetext{
${ }^{11}$ As a robustness check, we also consider all the information available prior to the forecasting year. In an alternative specification, we use the data from all previous years to predict the probability of success for each year of our late sample period (i.e. we use data on the campaigns from 2012 to 2015 to predict the success of equity crowdfunding campaigns in 2016 and data on the campaigns from 2012 to 2016 to predict the success of equity crowdfunding campaigns in 2017). The results (unreported) are similar to the results obtained with the threeyear rolling estimation windows.
} 
The results of our regressions confirm the importance of the determinants of success from the previous section. Across all three years, the amount of retained equity, the availability of previous external financing, accelerator attendance and follow-on raises have a highly significant positive effect on the probability of having a successful equity crowdfunding campaign. The age of the company and the campaign target amount seem to not predict success in equity crowdfunding. While the number of directors is significantly positively associated with success over all three forecasted years, their age seems to have a negative impact. The last section of Table 8 assesses the models' performance. The reported Hosmer-Lemeshow goodness-of-fit statistic is insignificant for all of our models, which indicates that the models fit the data well.

\subsection{Out-of-sample predictive performance}

To examine the strictly out-of-sample predictive performance of our models, we first derive the forecasted probability of success for each equity crowdfunding campaign (between 2015 and 2017) by fitting the relevant year's estimated coefficients to the campaign's variables. In other words, for each campaign we generate an ex-ante probability of success based upon the equity crowdfunding experience of the previous three years. Based on these out-of-sample predicted probabilities, we generate a binary prediction of equity crowdfunding success (i.e., whether equity crowdfunding success equals 0 or 1 ) using different cutoff values (e.g., 0.5). ${ }^{12}$ To test the predictive ability of our models, we cross-classify these binary predictions with the binary success variable for each year, i.e., we compare the true success outcome of each campaign in 2015, 2016, and 2017 to its out-of-sample forecasted probability (for similar approach, see Meoli et al. 2014). The classification results are reported in Table 9.

Sensitivity (the rate of correct predictions or true positive rate) refers to the proportion of successful campaigns that are correctly identified as such based on the out-of-sample forecasting model. In other words, it refers to the number of times the out-of-sample campaigns are correctly identified as successful divided by the total number of successful campaigns. The specificity (the

\footnotetext{
${ }^{12}$ In other words, if the out-of-sample predicted probability of a given campaign is larger (smaller) than the threshold of 0.5 , we assign a value of $1(0)$ to the binary prediction variable.
}

Table 8 Three-year rolling logistic regression estimations to forecast funding success

\begin{tabular}{|c|c|c|c|}
\hline & $\begin{array}{l}\text { Model (1): } \\
2015\end{array}$ & $\begin{array}{l}\text { Model (2): } \\
2016\end{array}$ & $\begin{array}{l}\text { Model (3): } \\
2017\end{array}$ \\
\hline Intercept & $\begin{array}{l}1.198 \\
(0.79)\end{array}$ & $\begin{array}{l}2.666^{* * *} \\
(2.19)\end{array}$ & $\begin{array}{l}3.615^{* * *} \\
(3.04)\end{array}$ \\
\hline Equity offered & $\begin{array}{l}-0.027 * * \\
(-2.52)\end{array}$ & $\begin{array}{l}-0.038 * * * \\
(-3.80)\end{array}$ & $\begin{array}{l}-0.047 * * * \\
(-4.64)\end{array}$ \\
\hline External financing & $\begin{array}{l}0.949 * * * \\
(4.62)\end{array}$ & $\begin{array}{l}0.781 * * * \\
(4.93)\end{array}$ & $\begin{array}{l}0.712^{* * * *} \\
(5.16)\end{array}$ \\
\hline Accelerator & $\begin{array}{l}1.573 * * * \\
(3.55)\end{array}$ & $\begin{array}{l}1.117^{* * * *} \\
(3.46)\end{array}$ & $\begin{array}{l}0.762^{* * * *} \\
(3.05)\end{array}$ \\
\hline $\begin{array}{l}\text { Number of directors } \\
\quad(\ln )\end{array}$ & $\begin{array}{l}0.359 * * \\
(2.19)\end{array}$ & $\begin{array}{l}0.358 * * * \\
(2.74)\end{array}$ & $\begin{array}{l}0.300^{* *} \\
(2.42)\end{array}$ \\
\hline Director age (ln) & $\begin{array}{l}-0.672^{* *} \\
(-2.15)\end{array}$ & $\begin{array}{l}-0.698^{* * *} \\
(-2.59)\end{array}$ & $\begin{array}{l}-0.818^{* * *} \\
(-3.08)\end{array}$ \\
\hline Follow-on campaign & $\begin{array}{l}1.451 * * * \\
(5.13)\end{array}$ & $\begin{array}{l}1.374 * * * \\
(5.80)\end{array}$ & $\begin{array}{l}1.009^{* * * *} \\
(4.39)\end{array}$ \\
\hline Platform Fixed Effects & Yes & Yes & Yes \\
\hline Industry Fixed Effects & Yes & Yes & Yes \\
\hline Number of successes & 282 & 472 & 590 \\
\hline Total observations & 928 & 1152 & 1229 \\
\hline Log likelihood & -494.34 & -684.81 & -768.79 \\
\hline Pseudo R sq. & 0.133 & 0.122 & 0.097 \\
\hline $\begin{array}{l}\text { Hosmer-Lemeshow } \chi \\
\text { sq. }\end{array}$ & 8.56 & 6.62 & 3.49 \\
\hline $\begin{array}{l}\text { Hosmer-Lemeshow } \\
\text { p-val }\end{array}$ & 0.381 & 0.578 & 0.900 \\
\hline
\end{tabular}

This table reports the results of our prediction model estimated using a three-year rolling window and applied out-of-sample to a sample of campaigns that were launched in the year indicated above. For example, for predicting equity crowdfunding success in 2015, we use data from 2012 to 2014 . We then roll the estimation window forward by one year to predict the likelihood of success in 2016. All specifications include industry fixed effects based on the main sections of NACE Rev. 2. Z-values are in parentheses. $* * *, * *$, and $*$ denote statistical significance at the $1 \%, 5 \%$, and $10 \%$ levels, respectively. See Table 2 for variable definitions

true negative rate) is measured as the proportion of correctly specified unsuccessful campaigns. In that sense, 1-specificity (the ratio between the predicted successful campaigns that were not successful in reality and the total number of unsuccessful campaigns) depicts a type II error. The overall correct rate refers to the overall rate of correct classification. Our models correctly classify around 60 to $64 \%$ of all campaigns at different cutoff values. This result implies that an entrepreneur or a platform employee using our forecasting model to predict equity crowdfunding success would be on average more than $60 \%$ correct. 
Table 9 Classification table

\begin{tabular}{llllll}
\hline Forecasted sample & Cutoff & Sensitivity & 1-Specificity & Overall correct rate & Adjusted success rate \\
\hline 2015 & 0.30 & 70.98 & 47.29 & 62.30 & 62.35 \\
& 0.35 & 62.05 & 35.96 & 63.00 & 65.57 \\
& 0.40 & 51.79 & 28.57 & 61.12 & 66.67 \\
& 0.45 & 45.98 & 20.69 & 61.83 & 71.03 \\
2016 & 0.50 & 37.50 & 16.75 & 59.25 & 71.19 \\
& 0.30 & 89.05 & 66.67 & 60.99 & 56.84 \\
& 0.35 & 82.38 & 53.05 & 64.54 & 60.49 \\
& 0.40 & 73.33 & 45.54 & 63.83 & 61.35 \\
& 0.45 & 65.71 & 36.62 & 64.54 & 63.89 \\
& 0.50 & 57.62 & 30.52 & 63.59 & 65.05 \\
& 0.30 & 90.20 & 83.11 & 62.60 & 64.24 \\
& 0.35 & 82.86 & 77.03 & 60.31 & 64.04 \\
& 0.40 & 78.78 & 62.84 & 63.10 & 67.48 \\
& 0.45 & 71.43 & 52.70 & 62.34 & 69.17 \\
& 0.50 & 68.16 & 45.95 & 62.85 & 71.06 \\
\hline
\end{tabular}

This table shows the comparison between the true success probability and the out-of-sample forecasted probability of each campaign in 2015, 2016, and 2017 at different cutoff values. Sensitivity is defined as the number of times the out-of-sample campaigns are correctly identified as successful over the total number of successful campaigns. 1-Specificity depicts the ratio between the predicted successful campaigns that were not successful in reality and the total number of unsuccessful campaigns. The overall correct rate refers to the overall rate of correct classification. The adjusted success rate is the ratio of correct predictions to the total number of predicted successful campaigns. The true success rate refers to the actual percentage of successful campaigns in the corresponding year

We additionally compute an adjusted success rate, which adjusts our rate of correct predictions for type II errors by estimating the ratio of correct predictions to the total number of predicted successful campaigns. This adjusted success rate has a more important and perhaps more interesting interpretation. If the decision to go live with an equity crowdfunding campaign was based solely on our model (i.e., all predicted successful campaigns launch and all predicted failed campaigns do not), the adjusted success rate for each year would range between $65 \%$ and $71 \%$ (for a cutoff value of 0.5 ). This is especially informative for platform organizers, who in 2015 were able to facilitate the success of only $52 \%$ of the campaigns, in $2016,50 \%$ of the campaigns, and in 2017, 62\% of the campaigns. Our simple forecasting model outperforms these outcomes for all years at different cutoff values.

Although informative, the classification method for evaluating forecasting performance suffers from a number of limitations (Demers and Joos 2007). First, the choice of a cutoff threshold is arbitrary, however, has a direct impact for measuring the forecasting ability of the model. Second, the continuous predicted probabilities estimated based on the forecasting model are collapsed into a binary outcome. And third, the classification is highly sensitive to the relative proportions of successful and unsuccessful campaigns in the sample. An alternative and perhaps more intuitive approach to presenting the model accuracy is provided by the ROC curve (Hosmer et al. 2013), which generalizes the classification table analysis by providing a graphical representation of the model performance for all possible cutoff values. The ROC curve plots the sensitivity against the type II error (or 1-specificity) of the logit model predictions, while the area under the ROC curve provides a measure of the model's ability to discriminate between successes and failures. We adopt this methodology as an additional assessment of our prediction models' accuracy. Figure 1 presents the ROC curves generated out-of-sample based on our forecasting models for each year, as well as the corresponding values for the areas under the ROC curves. A ROC value of 1 describes the best possible prediction model, which yields a point in the upper left corner of the graph corresponding to $100 \%$ specificity and $100 \%$ sensitivity. A ROC value of 0.5 , which corresponds to a 45 degree line (used as a benchmark in Fig. 1), represents a model with a predictive power equivalent to a coin toss. As evident from the figure, the areas under the ROC curves are $0.671,0.689$, and 0.648 for the year 2015 , 2016, and 2017 models respectively, all of which are considered as good levels of discrimination power 
Fig. 1 Receiver operating characteristic (ROC) curves for out-of-sample predictive performance
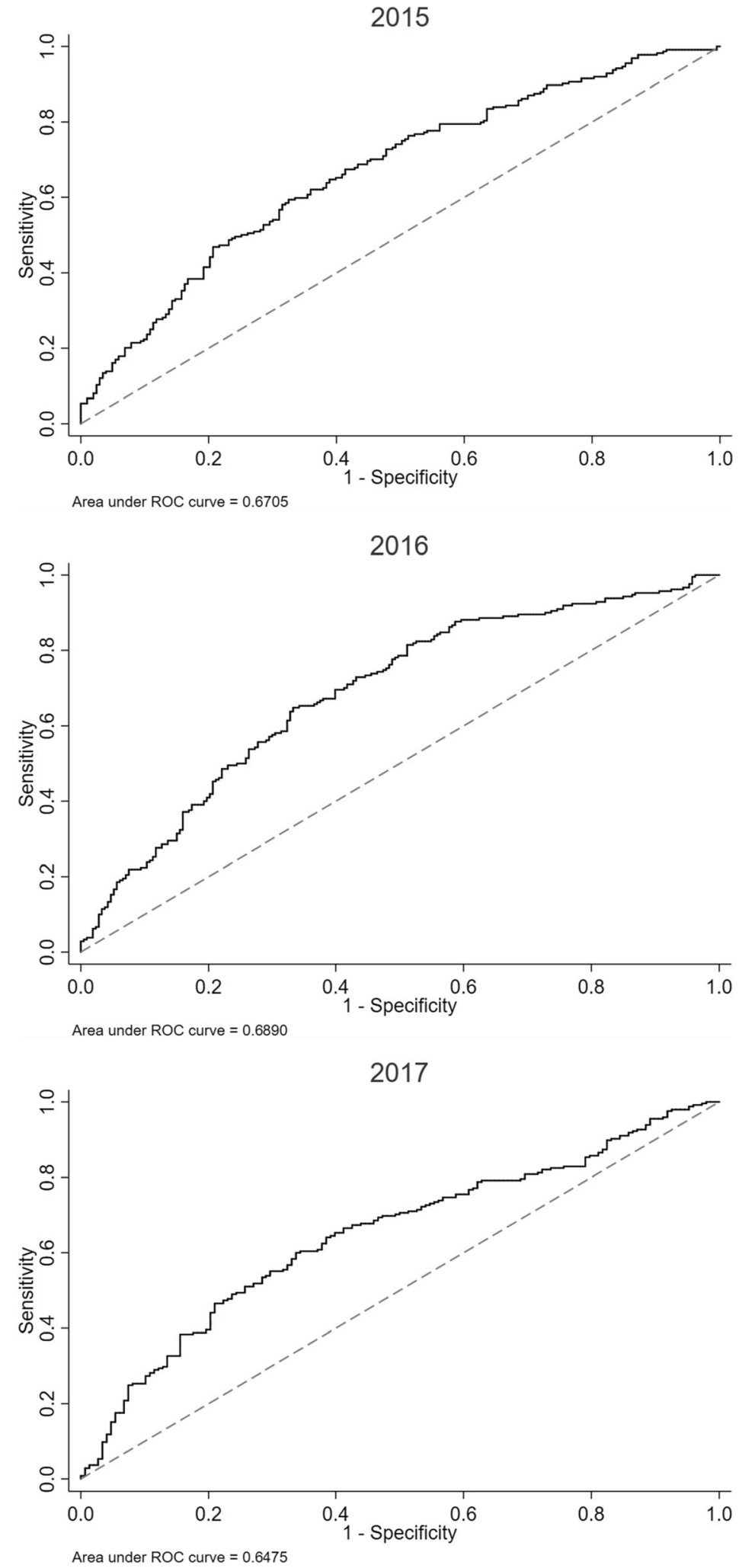
(Hosmer et al., 2013). Taken together, the out-of-sample tests we perform suggest that our forecasting models have sound predictive ability.

\section{Summary and conclusion}

While the existing body of research on equity crowdfunding has linked several campaign and company characteristics to success on equity crowdfunding platforms, this list of success factors is far from complete. Furthermore, the literature so far has tried to explain success in a single period of time, that way largely overlooking the dynamics over time. We try to fill this gap by examining thus far the largest and most comprehensive dataset of 2171 equity crowdfunding pitches launched between 2012 and 2017 on two of the world's largest platforms Crowdcube and Seedrs. Our goal is to develop a simple success prediction model based on publicly available information. Considering an extended set of characteristics that are potentially important for equity crowdfunding success, we first provide an overview of the evolution of equity crowdfunding campaigns over time. We show that more recent campaigns tend to be larger and are launched by older companies with better access to external financing. We interpret this finding as evidence for the maturity of the equity crowdfunding market. Second, we try to identify those characteristics that are associated with equity crowdfunding success. Consistent with previous literature, we find that retaining equity (Ahlers et al. 2015; Vismara 2016) is an important determinant of success in our setting, while extending the list of determinants to include external fundraising, accelerator attendance, as well as the number and age of directors, all of which significantly impact success on both Crowdcube and Seedrs. Next, we use these factors to develop a forecasting model to predict the probability of success of equity crowdfunding campaigns.

The findings of our forecasting exercise are especially informative for two of the parties involved in the equity crowdfunding process, namely the platforms and the entrepreneurs. We show that by employing a simple forecasting model platform organizers are able to improve the success outcomes on their equity crowdfunding websites. To the extent that the services offered by platforms influence the success of equity crowdfunding campaigns (see Rossi and Vismara 2018) and given that "success brings success" (see Signori and Vismara 2018), platform organizers can benefit from our findings in two important ways. First, our model can be used to generate targeted advice for entrepreneurs on how to improve their chances of success in equity crowdfunding. And second, our model can be used to refine the screening and due diligence process used by platforms when selecting which campaigns to allow on their websites. All this, combined with the existing effort of platform organizers, would result in improved success outcomes on the equity crowdfunding market. Furthermore, given that the equity crowdfunding market is continuously evolving (as also evident by our data), our parsimonious forecasting method can prove very useful to entrepreneurs as it utilizes a continuously updated (three-year rolling) model rather than a static model of the determinants of success. For entrepreneurs, there is always a trade-off between launching an equity crowdfunding campaign early and delaying it until a successful outcome is more likely. In that sense, our model can be used especially by first time entrepreneurs on the equity crowdfunding market to better time the launch of their pitch, but also by recurring entrepreneurs to reassess their attractiveness for the equity crowdfunding investors.

Our study is not without limitations. It is important to mention that our conclusions are based entirely on campaigns that successfully underwent the platforms' due diligence and our model does not take into account the campaigns that were screened out in the process. It may be of value for both platforms and entrepreneurs to consider how our parsimonious model applies to that currently ignored group of potential equity crowdfunding campaigns. Furthermore, our paper does not consider the perspective of the investors, as the scope of our forecasting model is limited to the success of the equity crowdfunding campaign alone. Given the high level of information asymmetries inherent to the equity crowdfunding market, there has been growing demand for business quality reassurance from investors. As more post-campaign information becomes available (e.g., for campaigns launched in 2017 only one year has passed, which is not enough to assess their ex-post performance), it would be interesting to assess how our model would apply for predicting post-campaign success outcomes.

Acknowledgments We thank two anonymous reviewers and the editor (Silvio Vismara) for their valuable comments on an earlier draft of this paper. 
Open Access This article is distributed under the terms of the Creative Commons Attribution 4.0 International License (http:// creativecommons.org/licenses/by/4.0/), which permits unrestricted use, distribution, and reproduction in any medium, provided you give appropriate credit to the original author(s) and the source, provide a link to the Creative Commons license, and indicate if changes were made.

Publisher's note Springer Nature remains neutral with regard to jurisdictional claims in published maps and institutional affiliations.

\section{References}

Ahlers, G. K., Cumming, D., Günther, C., \& Schweizer, D. (2015). Signaling in equity crowdfunding. Entrepreneurship Theory and Practice, 39(4), 955-980.

Bapna, S. (2017). Complementarity of signals in early-stage equity investment decisions: evidence from a randomized field experiment. Management Science, forthcoming.

Block, J., Hornuf, L., \& Moritz, A. (2018). Which updates during an equity crowdfunding campaign increase crowd participation? Small Business Economics, 50(1), 3-27.

Baum, J. A., \& Silverman, B. S. (2004). Picking winners or building them? Alliance, intellectual, and human capital as selection criteria in venture financing and performance of biotechnology start-ups. Journal of Business Venturing, 19(3), 411-436.

Beauhurst. (2017). The deal: equity investment in the UK 2017.

Coakley, J., Lazos, A., \& Liñares-Zegarra, J. M. (2018). Followon equity crowdfunding. In SSRN working paper.

Colombo, M. G., \& Grilli, L. (2010). On growth drivers of hightech start-ups: exploring the role of founders' human capital and venture capital. Journal of Business Venturing, 25(6), 610-626.

Cooper, A. C., Gimeno-Gascon, F. J., \& Woo, C. Y. (1994). Initial human and financial capital as predictors of new venture performance. Journal of Business Venturing, 9(5), 371-395.

Cumming, D., Leboeuf, G., \& Schwienbacher, A. (2019). Crowdfunding models: keep-it-all vs. all-or-nothing. Financial Management, forthcoming.

Cumming, D. J., \& Zhang, Y. (2018). Are crowdfunding platforms active and effective intermediaries? In SSRN working paper.

Demers, E., \& Joos, P. (2007). IPO failure risk. Journal of Accounting Research, 45(2), 333-371.

Estrin, S., Gozman, D., \& Khavul, S. (2018). The evolution and adoption of equity crowdfunding: entrepreneur and investor entry into a new market. Small Business Economics, 1-15.

Fehder, D.C., \& Hochberg, Y.V. (2018). Can accelerators accelerate local high-growth entrepreneurship? Evidence from venture-backed startup activity. University of Southern California working paper.

Florin, J., Lubatkin, M., \& Schulze, W. (2003). A social capital model of high-growth ventures. Academy of Management Journal, 46(3), 374-384.

Gonzalez-Uribe, J., \& Leatherbee, M. (2017). The effects of business accelerators on venture performance: evidence from 
start-up Chile. The Review of Financial Studies, 31(4), 15661603.

Hallen, B.L., S. Cohen, \& Bingham, C. (2018). Do accelerators accelerate? If so how? The impact of intensive learning from others on new venture development. University of Washington working paper.

Heeley, M. B., Matusik, S. F., \& Jain, N. (2007). Innovation, appropriability, and the underpricing of initial public offerings. Academy of Management Journal, 50(1), 209-225.

Hoenen, S., Kolympiris, C., Schoenmakers, W., \& Kalaitzandonakes, N. (2014). The diminishing signaling value of patents between early rounds of venture capital financing. Research Policy, 43(6), 956-989.

Hornuf, L., Schmitt, M., \& Stenzhorn, E. (2018). Equity crowdfunding in Germany and the United Kingdom: Follow-up funding and firm failure. Corporate Governance: An International Review, 26(5), 331-354.

Hornuf, L., \& Schwienbacher, A. (2017). Should securities regulation promote equity crowdfunding? Small Business Economics, 49(3), 579-593.

Hornuf, L., \& Schwienbacher, A. (2018). Market mechanisms and funding dynamics in equity crowdfunding. Journal of Corporate Finance, 50, 556-574.

Hosmer, D. W., Jr., Lemeshow, S., \& Sturdivant, R. X. (2013). Applied logistic regression. John Wiley \& Sons.

Hsu, D. H., \& Ziedonis, R. H. (2013). Resources as dual sources of advantage: implications for valuing entrepreneurial-firm patents. Strategic Management Journal, 34(7), 761-781.

Leland, H. E., \& Pyle, D. H. (1977). Informational asymmetries, financial structure, and financial intermediation. The Journal of Finance, 32(2), 371-387.

Long, C. (2002). Patent signals. The University of Chicago Law Review, 625-679.

Meoli, M., Migliorati, K., Paleari, S., \& Vismara, S. (2014). Forecasting winner IPOs. Investment Analysts Journal, 43(79), 41-49.

Mochkabadi, K., \& Volkmann, C. K. (2018). Equity crowdfunding: a systematic review of the literature. Small Business Economics, 1-44.
Mollick, E. (2014). The dynamics of crowdfunding: an exploratory study. Journal of Business Venturing, 29(1), 1-16.

Piva, E., \& Rossi-Lamastra, C. (2018). Human capital signals and entrepreneurs' success in equity crowdfunding. Small Business Economics, 51(3), 667-686.

Rossi, A., \& Vismara, S. (2018). What do crowdfunding platforms do? A comparison between investment-based platforms in Europe. Eurasian Business Review, 8(1), 93-118.

Rossi, A., Vismara, S., \& Meoli, M. (2018). Voting rights delivery in investment-based crowdfunding: a cross-platform analysis. Economia e Politica Industriale, forthcoming.

Signori, A., \& Vismara, S. (2018). Does success bring success? The post-offering lives of equity-crowdfunded firms. Journal of Corporate Finance, 50, 575-591.

Spence, M. (1973). Job market signaling. Quarterly Journal of Economics, 87, 355-374.

Stuart, T. E., Hoang, H., \& Hybels, R. C. (1999). Interorganizational endorsements and the performance of entrepreneurial ventures. Administrative Science Quarterly, 44(2), 315-349.

Vismara, S. (2016). Equity retention and social network theory in equity crowdfunding. Small Business Economics, 46(4), 579-590.

Vismara, S. (2018). Information cascades among investors in equity crowdfunding. Entrepreneurship Theory and Practice, 42(3), 467-497.

Vulkan, N., Åstebro, T., \& Sierra, M. F. (2016). Equity crowdfunding: a new phenomena. Journal of Business Venturing Insights, 5, 37-49.

Wilson, N., Wright, M., \& Kacer, M. (2018). The equity gap and knowledge-based firms. Journal of Corporate Finance, 50, 626-649.

Zacharakis, A. L., \& Meyer, G. D. (2000). The potential of actuarial decision models: can they improve the venture capital investment decision? Journal of Business Venturing, 15(4), 323-346. 